\title{
Música popular e identidades culturais
}

O debate acadêmico muitas vezes prioriza o entrelaçamento da produção musical brasileira com a formação da identidade nacional do país. Ainda assim, muitos músicos e compositores brasileiros atravessam as fronteiras do nacional e do popular, desestabilizam as classificações que determinam os gêneros e estilos musicais, desafiam linhas evolutivas e colocam em evidência as diversas matrizes étnicas de suas sonoridades. As múltiplas identidades culturais que esses artistas apresentam revelam os processos de migração, diáspora e globalização que compõem a música popular brasileira. Além disso, é preciso considerar os diversos circuitos de arte e redes de economia criativa pelos quais perpassam os músicos e compositores.

É sobre este amplo, complexo e importante tema que os artigos que compõem o Dossiê "Música popular e identidades culturais" deste número da revista TECAP pretendem refletir. Não se trata, obviamente, de propor um mapeamento da produção musical do país, mas sim apontar para as diversas abordagens que permeiam as composições de diversos artistas, com a atenção voltada para as proposições artísticas que atravessam a paisagem sonora do Brasil.

O conjunto de artigos reunidos no presente dossiê caminha nessa direção, deixando de lado qualquer expectativa de pureza ou autenticidade que possa circundar a música popular produzida no país, ou que tenha o Brasil como palco. Dessa forma, também são explorados, tanto de uma perspectiva histórica quanto antropológica, os impactos dessa produção em contextos que abordam dos ambientes locais aos globais e diaspóricos.

É essa produção múltipla, fragmentada, fronteiriça e que escapa das análises puristas sobre a música popular que interessa a este dossiê, principalmente no que diz respeito à sua importância para construção das diversas identidades culturais que engendram performances, ritmos e canções. 